\title{
MODEL PERILAKU INVESTOR KOTA MEDAN BERDASARKAN STRATEGI PEMASARAN
}

\author{
Arlina Nurbaity Lubis \\ arlinalubis@yahoo.com \\ Isfenti Sadalia \\ Khaira Amalia Fachrudin \\ Fakultas Ekonomi Universitas Sumatera Utara
}

\begin{abstract}
Behavioral finance is very important in one's decision-making when investing. Many factors affect the financial investors in the process of financial investment decision. This study aims to: (1) for test whether there is any difference in the financial investment decision process when viewed from demographic variables such as occupation, gender, and age of financial knowledge, (2) for test the influence of internal factors consisting of perception, motivation, learning, financial knowledge and external factors consisting of product, price, place/location, promotion, physical evidence, process, people and customer service to the investor's decision. The type of this research is descriptive quantitative. The sample in this study consist of 100 financial investors in the city of Medan. Discriminant and multiple regression analysis with stepwise method is used to test the hypothesis. The results showed: (1) there are significantly differences in the process of financial investment decisions based on demographic variables such as occupation, gender, and financial knowledge. While there was no difference in the financial investment decision process based on age categories, (2) process, motivation and customer service variable, have a positive and significant impact on investors' decision.
\end{abstract}

Keywords: investor behavior, marketing strategy, decision making

\begin{abstract}
ABSTRAK
Perilaku keuangan sangat berperan penting dalam pengambilan keputusan seseorang untuk berinvestasi. Banyak faktor yang mempengaruhi investor keuangan dalam proses keputusan investasi keuangannya. Penelitian ini bertujuan: (1) untuk menguji ada atau tidaknya perbedaan proses keputusan investasi keuangan jika dilihat dari variabel demografi seperti: pekerjaan, jenis kelamin, financial knowledge dan usia, (2) untuk menguji pengaruh faktor internal yang terdiri dari persepsi, motivasi, proses pembelajaran, financial knowledge, dan faktor eksternal yang terdiri dari produk, harga, tempat/lokasi, promosi, bukti fisik, proses, orang, dan pelayanan kepada pelanggan terhadap keputusan investor. Jenis penelitian ini adalah deskriptif kuantitatif. Sampel dalam penelitian ini terdiri dari 100 orang investor keuangan di kota Medan. Alat uji yang digunakan adalah Discriminant Analysis dengan metode stepwise dan stepwise regression untuk menguji hipotesis. Hasil penelitian menunjukkan: (1) terdapat perbedaan yang signifikan dalam proses keputusan investasi keuangan berdasarkan variabel demografi seperti pekerjaan, jenis kelamin, dan financial knowledge. Sementara itu tidak terdapat perbedaan proses keputusan investasi keuangan jika dilihat dari usia, (2) proses, motivasi dan customer service berpengaruh positif dan signifikan terhadap keputusan investor untuk berinvestasi.
\end{abstract}

Kata kunci : perilaku investor, strategi pemasaran, pengambilan keputusan

\section{PENDAHULUAN}

Pertumbuhan ekonomi masyarakat yang pesat menyebabkan investasi juga mengalami perkembangan yang cukup pesat. Perilaku keuangan sangat berperan dalam pengambilan keputusan seseorang untuk berinvestasi. Pengambilan keputusan keuangan untuk investasi, dipengaruhi oleh 
informasi yang diperoleh dan pengetahuan investor tentang keuangan dan investasi. Keputusan investasi seorang investor dapat dilihat dari dua sisi yaitu, (1) sejauh mana keputusan dapat memaksimalkan kekayaan (economic) dan (2) behavioral motivation (keputusan investasi berdasarkan aspek psikologis investor).

Tahun 2013 ini diwarnai dengan kasus investasi bodong. Total dana nasabah yang tersangkut di berbagai investasi bodong ataupun investasi yang masuk kategori mencurigakan minimal mencapai $\mathrm{Rp} 45$ triliun (Djumaeni, 2013). Investor perlu memiliki pengetahuan mengenai investasi dan perlu mempertanyakan kejelasan suatu investasi. Investor perlu mewaspadai tawaran investasi dan mempertanyakan surat dari Otoritas Jasa Keuangan atau Badan Pengawas Perdagangan Berjangka Komoditi (Bappebti).

Investasi bodong memiliki ciri sebagai berikut: memberikan iming-iming tingkat imbal hasil yang sangat tinggi (high rate of return), memberi jaminan bahwa investasi tak memiliki risiko investasi (free risk), memberi bonus dan cashback yang sangat besar, menyalahgunakan testimoni dari pemuka masyarakat (endorsement), memberi janji kemudahan menarik kembali aset dan jaminan keamanan (easy, flexible, and safe), serta jaminan pembelian tanpa pengurangan nilai (buy back guarantee) (Badriyah, 2013).

Berdasarkan utility theory yang dikembangkan oleh Von dan Morgenstern (1947) mengatakan bahwa (1) investor sangat rasional, (2) setuju dengan pilihan yang kompleks, (3) tidak suka risiko, dan, (4) memaksimalkan kekayaan. Dengan adanya perkembangan dari masa ke masa, maka muncullah teori lain yang dapat mempengaruhi keputusan investasi investor berdasarkan aspek psikologis (behavioral motivation). Selain itu, studi empiris tentang perilaku investor yang dilakukan oleh Blume dan Irwin pada tahun 1978, menunjukkan variabel demografi mempengaruhi proses pemilihan dan komposisi portofolio investasi.
Lewellen et al. (1977) menyatakan bahwa usia, jenis kelamin, pendapatan dan pendidikan mempengaruhi pilihan investor untuk keuntungan, dividen dan semua laba yang diinginkan. Selain itu, Warren et al. (1990) menyatakan bahwa pilihan investasi seseorang lebih berdasar pada gaya hidup dan karakteristik demografinya. Kebanyakan investor dalam keputusan berinvestasi hanya melihat dan mempertimbangkan faktor Accounting Information agar tujuan investasinya tercapai, namun faktor-faktor yang lain tidak banyak diperhatikan. Faktor tersebut biasa disebut sebagai alat analisis tradisional dan investor biasanya sudah merasa cukup dengan melihat kedua faktor tersebut untuk menentukan keputusan investasi, selain itu memang banyak investor yang tidak mengetahui bahwa ada faktor lain yang dapat dijadikan pertimbangan sebelum melakukan investasi.

Nagy dan Obenberger (1994) dalam penelitiannya mengklasifikasikan beberapa faktor lain selain Accounting Information dan Self Image/Firm-Image Coincidence yang juga mempengaruhi seorang investor dalam melakukan investasi yaitu faktor Neutral Information, Classic, Social Relevance, Advocate Recommendation, dan Personal Financial Needs.

Penelitian Nagy dan Obenberger menyatakan bahwa investor sekarang berbeda, tidak lagi hanya melihat faktor yang sudah biasa saja tapi juga memperhitungkan faktor lain sebelum melakukan investasi, dan faktor yang paling diperhitungkan oleh investor adalah estimasi keuntungan perusahaan di masa datang yang merupakan variabel economics untuk memaksimalkan kekayaan. Al-Tamimi (2006) menyatakan bahwa estimasi laba perusahaan adalah faktor yang paling berpengaruh dalam pengambilan keputusan, sedangkan faktor religius tidak memberikan pengaruh terhadap pengambilan keputusan investasi.

Konsumen adalah makhluk sosial yang dipengaruhi oleh lingkungan sosialnya. Menurut Kotler dan Amstrong (2008), berdasarkan kedekatannya dengan konsumen maka lingkungan dapat dibagi dua, yaitu lingkungan mikro dan lingkungan makro. 
Lingkungan mikro adalah lingkungan yang sangat dekat dengan konsumen, yang berinteraksi langsung dengan konsumen seperti penjual, teman, dan lain sebagainya, sedangkan lingkungan makro adalah lingku ngan jauh yang berskala besar, misal nya sistem politik dan hukum, lingkungan ekonomi dan budaya.

Berdasarkan pemikiran di atas serta didukung penelitian empiris yang telah diuraikan sebelumnya, masih belum ada pengujian secara komprehensif yang melibatkan tentang: (1) Bagaimana pola yang membentuk perilaku investasi melalui perbedaan pengambilan keputusan jika dilihat dari kelompok usia, jenis kelamin, pekerjaan dan financial knowledge?; (2) Bagaimana pengaruh faktor internal yang terdiri dari persepsi, motivasi, proses pembelajaran, financial knowledge dan faktor eksternal yang terdiri dari produk, harga, tempat/lokasi, promosi, bukti fisik, proses, orang dan pelayanan kepada pelanggan terhadap keputusan investor.

Penelitian ini bertujuan untuk menganalisis dan menjelas tentang: (1) Pola yang membentuk perilaku investasi melalui perbedaan pengambilan keputusan investasi jika dilihat dari kelompok usia, jenis kelamin, pekerjaan dan financial knowledge; (2) Pengaruh faktor internal yang terdiri dari persepsi, motivasi, learning process, financial knowledge dan faktor eksternal yang terdiri dari produk, harga, tempat/lokasi, promosi, bukti fisik, orang, proses, dan pelayanan pelanggan terhadap keputusan investor.

\section{TINJAUAN TEORETIS \\ Perilaku Konsumen \\ Pengertian Perilaku Konsumen}

Perilaku konsumen merupakan tindakan yang langsung terlibat dalam mendapatkan, mengkonsumsi, dan menghabiskan produk atau jasa, termasuk proses keputusan yang mendahului dan menyusul tindakan ini. Perilaku konsumen merujuk pada perilaku membeli konsumen akhir individu dan rumah tangga yang membeli barang dan jasa untuk konsumsi pribadi (Kotler dan Amstrong, 2008: 158).

Perusahaan harus mampu memahami apa yang dipikirkan, dirasakan, dilakukan oleh konsumen sehubungan dengan pemenuhan keinginan dan kebutuhannya. Hanya perusahaan yang benar-benar mampu memahami setiap respon konsumen yang akan memiliki keunggulan yang lebih besar atas pesaingnya.

Bagi perusahaan, pikiran dan perasaan konsumen adalah sebuah misteri yang tidak ada habisnya, namun memahaminya merupakan kunci penting jika pemasar ingin sukses (Kotler dan Amstrong, 2008). Oleh karena itu pertanyaan inti untuk pemasar adalah, bagaimana konsumen merespon berbagai usaha pemasaran yang mungkin digunakan perusahaan? Titik awalnya adalah model perilaku pembelian berupa rangsangan-tanggapan yang diperlihatkan pada Gambar 1.

Rangsangan pemasaran terdiri dari empat P yaitu, product, price, place dan promotion. Rangsangan lain meliputi kekuatan dan faktor utama dalam lingkungan pembeli: ekonomi, teknologi, politik dan budaya. Semua masukan ini memasuki kotak hitam pembeli, dimana masukan ini diubah menjadi sekumpulan respon pembeli yang dapat diobservasi: pilihan produk, pilihan merek, pilihan penyalur, waktu pembelian dan jumlah pembelian.

\section{Faktor Yang Mempengaruhi Perilaku Konsumen}

Menurut Kotler dan Amstrong (2008: 159) terdapat beberapa faktor yang mempengaruhi perilaku konsumen, yaitu: (1) Faktor Budaya, terdiri dari: sub budaya, kelas sosial; (2) Faktor Sosial, terdiri dari: kelompok referensi, keluarga, peran, dan status; (3) Faktor Pribadi, terdiri dari: usia dan tahap siklus hidup, pekerjaan, situasi ekonomi, gaya hidup, kepribadian dan konsep diri; (4) Faktor Psikologis, terdiri dari: motivasi, persepsi, pembelajaran, kepercayaan, dan sikap. 


\begin{tabular}{|c|c|c|c|}
\hline \multicolumn{2}{|c|}{ Pemasaran dan Rangsangan lain } & \multirow{2}{*}{$\begin{array}{l}\begin{array}{c}\text { Kotak Hitam } \\
\text { Pembeli }\end{array} \\
- \text { Karakteristik } \\
\text { pembeli } \\
-\begin{array}{l}\text { Proses } \\
\text { keputusan } \\
\text { pembeli }\end{array} \\
\end{array}$} & \multirow{2}{*}{$\begin{array}{l}\text { Respon Pembeli } \\
\\
\text { Pilihan Produk } \\
\text { Pilihan Merek } \\
\text { Pilihan Penyalur } \\
\text { Waktu Pembelian } \\
\text { Jumlah Pembelian }\end{array}$} \\
\hline $\begin{array}{c}\text { Bauran Pemasaran } \\
\text { Produk } \\
\text { Harga } \\
\text { Tempat } \\
\text { Promosi }\end{array}$ & $\begin{array}{c}\text { Rangsangan Lain } \\
\text { Ekonomi } \\
\text { Teknologi } \\
\text { Politik } \\
\text { Budaya }\end{array}$ & & \\
\hline
\end{tabular}

\section{Gambar 1}

Model Perilaku Konsumen

Dalam proses pengambilan keputusan untuk membeli suatu produk, konsumen akan melalui lima tahapan, yaitu: (1) Pada tahap pengenalan kebutuhan konsumen menyadari adanya suatu masalah atau kebutuhan. Kebutuhan dapat dipicu oleh rangsangan internal/eksternal; (2) Pada tahap pencarian informasi, konsumen ingin mencari informasi lebih banyak; (3) Evaluasi alternatif yaitu tahap proses keputusan pembeli dimana konsumen menggunakan informasi untuk mengevaluasi merek alternatif dalam sekelompok pilihan; (4) Keputusan pembelian yaitu keputusan pembeli tentang merek mana yang dibeli. Keputusan pembelian konsumen adalah membeli merek yang paling disukai; (5) Perilaku pasca pembelian yaitu tahap proses keputusan pembeli dimana konsumen mengambil tindakan selanjutnya setelah pembelian, berdasarkan kepuasan atau ketidak puasan mereka.

Kepuasan konsumen terjadi pada saat konsumen mengevaluasi bahwa kinerja aktual produk ataupun layanan yang diberikan sesuai dengan ekspektasi mereka. Oleh karena itu jelas bahwa kepuasan konsumen mempunyai hubungan dengan kinerja. Di samping itu, untuk senantiasa mampu memenuhi harapan konsumen maka perusahaan harus selalu memonitor konsumennya dengan menggunakan relationship marketing (Laksana, 2008:14) yaitu menjalin hubungan baik jangka panjang dengan konsumennya. Selanjutnya kepuasan konsumen akan menyebabkan pembelian ulang atau yang dikenal dengan customer loyalty. Sebagaimana Chen (1999) dalam penelitiannya membuktikan bahwa reputasi dan kualitas pelayanan berpengaruh terhadap kesuksesan bank, diikuti kemampuan manajemen menjaga hubungan dengan konsumen, kecanggihan pelayanan, teknologi, likuiditas bank, lokasi bank serta jumlah kantor cabang dan lain-lain.

Andreassen dan Tor (1994) dalam penelitiannya menemukan bahwa kepuasan, loyalitas dan reputasi merek sangat memegang peranan penting di dalam sektor publik untuk meraih keunggulan mereka dalam jangka panjang. Disamping itu, Bloemer dan Pasca (1998) dalam kajian yang dilakukannya juga membuktikan bahwa loyalitas nasabah sangat dipengaruhi oleh beberapa faktor diantaranya reputasi bank yang baik serta kualitas pelayanan yang diberikan kepada nasabah dan kepuasan nasabah.

\section{Keputusan Investasi}

Investasi merupakan penempatan sejumlah dana pada saat ini dengan harapan dapat menghasilkan keuntungan di masadepan (Halim, 2005). Sehingga dalam melakukan keputusan investasi, investor memerlukan informasi yang merupakan faktor penting sebagai dasar untuk menentukan pilihan investasi. Dari informasi yang ada, terbentuk suatu model pengambilan ke putusan yang berupa kriteria penilaian investasi untuk memungkinkan investor memilih investasi terbaik di antara alternatif investasi yang tersedia.

Utility theory adalah teori yang digunakan untuk menjelaskan sikap sese- 
orang terhadap risiko. Dalam penelitian ini sikap investor dalam melakukan investasi untuk menghindari risiko agar dapat memaksimalkan kekayaan (economic factor). Behavioral motivation yaitu keputusan investasi berdasarkan psikologi investor atau sesuatu yang diyakininya, yang meliputi faktor Self Image/Firm-Image Coincidence, Social Relevance, Advocate Recommendation, Personal Financial Needs. Neutral Information merupakan informasi berasal dari luar yang menunjukkan gambaran agar informasi yang didapat tidak berat sebelah, informasi ini mencangkup ulasan dan informasi dari media tentang keuangan maupun keadaan ekonomi yang berhubungan dengan kegiatan investasi yang meliputi informasi tentang pemberitaan atau ulasan di media keuangan yang biasanya membahas tentang keadaan atau kondisi saat ini dengan perkembangan investasi yang ada serta halhal lain yang berhubungan dengan investasi dan keuangan, pemberitaan atau ulasan di media umum, perubahan harga saham, ulasan dari analis keuangan yang dipublikasikan di media, dan indikator ekonomi (inflasi, tingkat suku bunga, dan lain-lain) (Nagy dan Obenberger, 1994).

Accounting Information yaitu informasi yang berhubungan dengan laporan keuangan perusahaan (Nagy dan Obenberger, 1994). Self Image/Firm-Image Coincidence merupakan informasi yang berhubungan dengan penilaian terhadap perusahaan, meliputi informasi tentang reputasi perusahaan, posisi perusahaan pada industri yaitu termasuk market leader atau market follower, new comers, perkiraan produk dan pelayanan perusahaan, mengetahui etika-etika perusahaan, (Nagy dan Obenberger, 1994). Classic merupakan kemampuan investor menentukan kriteria pada dasar ekonomis dari perilaku investor, meliputi informasi kemampuan untuk memperkecil risiko (Nagy dan Obenberger, 1994).

Social Relevance menunjukkan informasi keberadaan perusahaan dan tanggung jawab sosial perusahaan (Nagy dan Obenberger, 1994). Advocate Recommendation merupakan sumber informasi dalam membangun gagasan dan pemahaman berdasar- kan rekomendasi yang telah diberikan dengan memperhatikan kepentingan dalam hasil pada kegiatan pokok investor, hal ini juga diungkapkan oleh Toral (2002) bahwa investor dalam pemilihan investasi membutuhkan tenaga profesional sehingga tidak ada kecemasan dalam memilih investasi di saat keadaan pasar sedang lesu, informasi tersebut meliputi rekomendasi dari penasehat keuangan, rekomendasi dari teman, dan pendapat dari keluarga (Nagy dan Obenberger, 1994).

Personal Financial Needs diperoleh berdasarkan pengalaman investor dalam melihat nilai investasi dan perhitungan pada pengeluaran konsumsi yang meliputi informasi tentang target hasil dari investasi untuk memenuhi keuangan pribadi, estimasi dana untuk investasi, keinginan diversifikasi, kinerja portofolio saham yang dimiliki di masa yang lalu, serta alternatif investasi lain selain yang telah dimiliki (Nagy dan Obenberger, 1994).

Berdasarkan teori portofolio, bahwa para investor bisa melakukan diversifikasi dengan membentuk portofolio karena ingin mengurangi risiko. Namun ada juga risiko yang sifatnya sistematis karena risiko ini sangat dipengaruhi oleh kondisi perekonomian. Hasil penelitian yang dilakukan Kumar (2009), menunujukkan bahwa seorang investor lebih memperhatikan komposisi portofolio karena ini mempengaruhi pendapatan dalam jangka panjang, pendapatan yang didapat dari portofolio sebelumnya, informasi tentang investasi yang diperoleh melalui media, dan hal yang paling utama adalah mempertimbangkan keadaan makro ekonomi dalam memperkirakan aliran dana di masa yang akan datang.

Suatu investasi dapat dikatakan menguntungkan (profitable) jika investasi tersebut dapat menjadikan investor lebih kaya atau tingkat kemakmuran investor menjadi lebih baik setelah melakukan investasi.

Berdasarkan teori tersebut maka perusahaan jasa keuangan harus memperhatikan strategi pemasarannya. Dalam hal ini ada beberapa instrumen pemasaran jasa termasuk jasa keuangan yang dapat di- 
gunakan oleh perusahaan dalam memasarkan jasanya, yaitu yang dikenal dengan bauran pemasaran jasa yang terdiri dari: produk, harga, tempat/lokasi, promosi, bukti fisik, orang/SDM, proses dan pelayanan kepada pelanggan (Kotler dan Amstrong, 2008).

\section{Faktor Demografi Investor}

Menurut Lewellen et al. (1977), terdapat faktor lain yang dapat mempengaruhi keputusan investasi yang dapat dilihat dari variabel demografi, seperti: jenis kelamin, usia, tingkat pendapatan, dan tingkat pendidikan.

\section{Penelitian terdahulu}

Penelitian terdahulu yang dilakukan oleh Jain dan Mandot (2012) mengenai Impact of Demographic Factors on Investment Decision of Investors in Rajasthan, yang menguji apakah ada pengaruh faktor demografi terhadap keputusan investor. Populasi penelitian ini terdiri dari 200 investor yang tersebar diberbagai kota di Rajhastan dengan batasan waktu April 2011 hingga Januari 2012. Penelitian ini menggunakan metode Chi-Square dan analisis korelasi. Hasil penelitian membuktikan terdapat korelasi positif antara variabel kota, tingkat pendapatan dan pengetahuan. Berdasarkan penelitian ini juga diperoleh hasil korelasi negatif antara status pernikahan, jenis kelamin, umur, tingkat pendidikan dan jabatan pekerjaan.

Penelitian terdahulu yang dilakukan oleh Meliza (2014) mengenai Pengaruh Perilaku Keuangan Terhadap Keputusan Investor dan Performa Investasi Saham di Kota Medan. Performa investasi dipengaruhi oleh perilaku keuangan dan keputusan investor, yang menguji apakah ada pengaruh antara perilaku keuangan terhadap keputusan investor dan performa investasi saham di kota Medan. Hasil penelitian menunjukan bahwa perilaku keuangan berpengaruh secara langsung maupun secara tidak langsung terhadap keputusan investor dan performa investasi. Terbukti pengaruh langsung variabel perilaku keuangan ke variabel keputusan memiliki nilai lebih besar dibandingkan dengan pengaruh langsung ke variabel performa. Alat analisis dalam penelitian ini menggunakan analisis jalur. Berdasarkan hasil penelitian dapat diambil kesimpulan bahwa keputusan investor yang melakukan investasi saham khususnya di kota Medan dipengaruhi heuristik dengan nilai paling signifikan dibandingkan variabel lainnya pada tingkat alpha 5\%.

Penelitian terdahulu yang dilakukan oleh Kabra et al. (2010) mengenai Factors Influencing Investment Decision of Generations in India, yang menguji tentang faktor-faktor utama yang mempengaruhi perilaku investasi dan bagaimana faktor tersebut berdampak pada resiko toleransi investasi dan proses pengambilan keputusan di antara pria dan perempuan dan di antara kelompok usia yang berbeda. Populasi penelitian ini terdiri dari investor, yang secara teratur berinvestasi di India. Penelitian ini mengikuti metodologi penelitian survei. Studi ini menyimpulkan bahwa usia investor dan jenis kelamin merupakan faktor dominan saat memutuskan kapasitas pengambilan risiko investor.

Penelitian terdahulu yang dilakukan oleh Karthikeyan (2001) telah melakukan penelitian tentang Persepsi Investor skala kecil pada skema post office saving, menemukan bahwa ada perbedaan yang signifikan antara empat kelompok usia, di tingkat awareness untuk Kisan Vikas Patra (KVP), Skema Tabungan Nasional (NSS), dan skema deposito untuk Pensiunan Karyawan (DSRE), dan secara keseluruhan skor dikonfirmasi bahwa tingkat kesadaran kalangan investor pada kelompok usia tua lebih tinggi dibandingkan orang-orang dari kelompok usia muda tidak ada perbedaan yang diamati antara investor pria dan wanita kecuali NSS dan KVP.

Penelitian terdahulu yang dilakukan oleh Barber dan Odean (2000) mengeksplorasi dampak pemikiran intuitif pada preferensi investasi dan mempelajari pengalaman dari investor sebenarnya, yang menyediakan proxy alami untuk overconfidence-gender. Penelitian psikologis telah menetapkan bahwa laki-laki lebih percaya 
diri daripada wanita melakukan keputusan investasi. Dengan menggunakan data account untuk lebih dari 35.000 rumah tangga dari sebuah perusahaan broker, penelitian ini menganalisis investasi saham biasa dari pria dan wanita dari Februari 1991 hingga Januari 1997. Sesuai dengan prediksi model overconfident didokumentasikan bahwa perdagangan yang dilakukan pria 45 persen lebih besar dari perempuan, dan mendapatkan kembali yang disesuaikan resiko bersih tahunan yang 1,4 persen lebih sedikit daripada yang diterima oleh perempuan. Perbedaan ini lebih jelas antara laki-laki tunggal dan perempuan tunggal; pria lajang perdagangan 67 persen lebih besar daripada wanita lajang, dan mendapatkan kembali resiko bersih tahunan yang disesuaikan dengan nilai 2,3 persen lebih sedikit daripada yang diterima oleh wanita lajang.

Penelitian terdahulu yang dilakukan oleh Iramani dan Bagus (2008), membahas tentang faktor-faktor psikologi yang menjelaskan perilaku investor dalam jual beli saham di Bursa Efek Jakarta dan perbedaan signifikan faktor-faktor pembentuk perilaku antara investor pria dan investor wanita. Penelitian ini menggunakan sampel investor yang menginvestasikan dananya di bursa modal dalam bentuk saham dan melakukan transaksi jual beli saham di Bursa Efek Jakarta yang berlokasi di Surabaya dan sekitarnya.

Teknik analisis yang digunakan oleh si peneliti adalah analisis faktor yang bertujuan untuk mengetahui hal apa saja yang menjadi faktor psikologi yang dapat membentuk perilaku investor dalam pengambilan keputusan jual beli saham. Peneliti juga menggunakan uji beda dalam penelitian ini untuk mengetahui perbedaan signifikan antara faktor-faktor pembentuk perilaku antara investor pria dan investor wanita. Hasil dari penelitian menyimpulkan bahwa dari 16 konstruk awal dapat direduksi menghasilkan enam faktor yang memiliki nilai kumulatif variance sebesar 64,385 persen yang terdiri dari: keamanan dan kenyamanan, bias pemikiran, keberanian, kepercayaan diri, interaksi sosial dan emosi, dan bias penilaian. Berdasarkan uji beda yang dilakukan dapat disimpulkan bahwa tidak ada perbedaan signifikan faktor pembentuk perilaku antara perilaku investor pria dan investor wanita dalam melakukan transaksi saham.

\section{Hipotesis}

Berdasarkan kajian teori dan hasil penelitian yang dikemukakan, dapat dibangun hipotesis penelitian, yaitu: (1) Terdapat perbedaan pengambilan keputusan jika dilihat dari kelompok usia, jenis kelamin, pekerjaan, dan financial knowledge; (2) Terdapat pengaruh signifikan antara faktor internal yang terdiri dari persepsi, motivasi, proses pembelajaran, financial knowledge dan faktor eksternal yang terdiri dari produk, harga, tempat/lokasi, promosi, bukti fisik, proses, orang dan pelayanan kepada pelanggan terhadap keputusan investor.

\section{METODE PENELITIAN}

Penelitian ini merupakan jenis penelitian deskriptif kuantitatif. Populasi dalam penelitian ini adalah investor keuangan kota Medan dengan jumlah 1000 investor, sedangkan metode sampling yang digunakan dalam penelitian ini dengan pemilihan sampel random (random sampling), dimana proses pemilihan sampel sedemikian rupa sehingga semua orang dalam populasi mempunyai kesempatan dan kebebasan yang sama untuk terpilih sebagai sampel (Sumanto, 2002: 47).

Penentuan jumlah sampel apabila subyeknya kurang dari 100 lebih baik diambil semua sehingga penelitiannya merupakan penelitian populasi. Selanjutnya, jika jumlah subyeknya besar dapat diambil antara $10-15 \%$ atau $20-25 \%$ atau lebih tergantung dari kemampuan peneliti, luas wilayah penelitian dan besar kecilnya risiko peneliti (Arikunto, 2002: 112). Jumlah sampel yang diambil dalam penelitian ini sebesar 100 responden $(10 \%$ x $1000=100)$ yang dipilih secara acak.

Data yang digunakan dalam penelitian ini bersumber pada data primer yang diperoleh dengan menggunakan kuesioner yang diberikan kepada responden dengan 
tujuan untuk mengumpulkan informasi dari responden pada lokasi penelitian.

Penelitian ini menggunakan Discriminant Analysis (analisis diskriminan) dengan metode stepwise yang digunakan untuk memodelkan suatu hubungan antara variabel dependen yang berdata kategori dengan beberapa variabel independen (prediktor). Analisis diskriminan juga mengelompokkan setiap objek kedalam dua atau lebih kelompok berdasarkan pada sejumlah kriteria variabel independen. Dalam penelitian ini ada empat kelompok yaitu kelompok usia, jenis kelamin, pekerjaan dan financial knowledge yang dilihat bagaimana kriterianya yang berbeda terhadap faktor-faktor: persepsi, motivasi, learning process, produk, harga, lokasi/tempat, promosi, bukti fisik, orang/SDM, proses dan pelayanan kepada investor/nasabah.

Penelitian ini menguji ada tidaknya perbedaan keputusan investor yang ditinjau dari kelompok usia, jenis kelamin, pekerjaan, dan financial knowledge. Uji instrumen dilakukan melalui uji validitas dan reliabilitas. Menguji ketepatan kuesioner akan dilakukan pretest terhadap 100 responden di beberapa perusahaan sekuritas dan jasa keuangan di Medan.

Validitas menunjukkan seberapa akurat suatu alat pengukur atau kuesioner mampu mengukur apa yang diukur. Uji validitas digunakan untuk mengukur sah atau valid tidaknya suatu kuesioner (Ghozali, 2011: 121). Uji signifikasi dilakukan dengan membandingkan antara nilai $r$ hitung dan $r$ tabel, dengan degree of freedom $(\mathrm{df})=\mathrm{n}-2, \mathrm{n}$ adalah/sama dengan jumlah sampel. Pada tampilan output SPSS pada kolom Corrected Item-Total Correlation, jika $r_{\text {hitung }}$ lebih besar dari $r_{\text {tabel }}$ dan memiliki nilai positif, maka butir pertanyaan atau indikator tersebut dinyatakan valid. Uji reliabilitas dilakukan untuk mengetahui konsistensi atau kepercayaan hasil ukur yang cermat. Ghozali (2011: 122) memberikan batasan suatu variabel handal (reliabel) jika Cronbach Alpha >0,6, maka untuk memperoleh angka Cronbach Alpha dilakukan pengolahan data dengan bantuan program SPSS.
Analisis diskriminan berusaha mengelompokkan setiap objek ke dalam dua atau lebih kelompok berdasarkan pada sejumlah kriteria variabel independen. Analisis diskriminan dalam penelitian ini menggunakan metode stepwise yang digunakan untuk memodelkan suatu hubungan antara variabel dependen yang berdata kategori dengan beberapa variabel independen (prediktor). Analisis diskriminan juga mengelompokkan setiap objek kedalam dua atau lebih kelompok berdasarkan pada sejumlah kriteria variabel independen.

Keputusan investor untuk investasi pada jasa keuangan berdasarkan usia dibedakan dengan kode: (1) Kode $1=$ Usia lebih kecil sama dengan 40 tahun; (2) Kode 2=Usia yang lebih dari 40 tahun. Keputusan investor untuk investasi pada jasa keuangan berdasarkan jenis kelamin dibedakan dengan kode: (1) Kode $1=$ pria; (2) Kode $2=$ perempuan. Keputusan investor untuk investtasi pada jasa keuangan berdasarkan pekerjaan dibedakan dengan kode: (1) Kode 1 = keuangan; (2) Kode 2 = non keuangan. Keputusan investor untuk investasi pada jasa keuangan berdasarkan financial knowledge dibedakan dengan kode: (1) Kode $1=$ financial knowledge di atas rata-rata; (2) Kode $2=$ financial knowledge di bawah rata-rata.

Penelitian ini juga menggunakan analisis regresi linier berganda dengan menggunakan metode stepwise untuk menguji bagaimana pengaruh independent variabel yang dalam hal ini faktor internal seperti persepsi, motivasi, learning process dan financial knowledge dan faktor eksternal seperti produk, harga, tempat/lokasi, promosi, bukti fisik, orang, proses, dan pelayanan kepada pelanggan terhadap dependent variabel yaitu keputusan investor untuk berinvestasi pada jasa keuangan.

\section{ANALISIS DAN PEMBAHASAN Hasil Statistik Deskriptif}

Terlihat pada tabel 1 frekuensi untuk jenis kelamin bahwa responden laki-laki berjumlah 42 orang dan responden wanita berjumlah 58 orang dengan total 100 orang responden. 
Tabel 1

Tabel Frekuensi Jenis Kelamin

\begin{tabular}{llcc}
\hline \hline & & Frekuensi & Persen \\
\hline Valid & Laki-laki & 42 & $42 \%$ \\
& Perempuan & 58 & $58 \%$ \\
& Total & 100 & $100 \%$ \\
\hline
\end{tabular}

Sumber : Hasil olahan data penelitian (2013)

Tabel 2

Tabel Frekuensi Usia

\begin{tabular}{llrr}
\hline \hline & & Frekuensi & Persen \\
\hline Valid & $<40$ tahun & 65 & $65 \%$ \\
& $>40$ tahun & 35 & $35 \%$ \\
& Total & 100 & $100 \%$ \\
\hline
\end{tabular}

Sumber : Hasil olahan data penelitian (2013)

Pada tabel 2 frekuensi untuk usia yakni responden $>40$ tahun berjumlah 65 orang dan responden wanita berjumlah 35 orang, dengan total keseluruhan 100 responden.

Tabel 3

Tabel Frekuensi Pekerjaan

\begin{tabular}{llcc}
\hline \hline \multirow{2}{*}{ Valid } & & Frekuensi & Persen \\
\cline { 2 - 3 } & Keuangan & 20 & $20 \%$ \\
& Non & & \\
& Keuangan & 80 & $80 \%$ \\
& Total & 100 & $100 \%$ \\
\hline
\end{tabular}

Sumber: Hasil olahan data penelitian (2013)

Pada tabel 3 fekuensi untuk pekerjaan dapat diketahui bahwa responden yang pekerjaannya terkait dengan bidang keuangan yakni 20 responden, sedangkan pada bidang pekerjaan yang non-keuangan sebanyak 80 responden.

Tabel 4 frekuensi financial knowledge diketahui tingkat financial knowledge responden yang rendah yaitu 45 responden, sedangkan tingkat financial knowledge responden yang tinggi yaitu 55 responden.

Tabel 4

Tabel Frekuensi Financial knowledge

\begin{tabular}{clcc}
\hline \hline \multirow{6}{*}{ Valid } & Frekuensi & Persen \\
\cline { 2 - 3 } & Rendah & 45 & $45 \%$ \\
& Tinggi & 55 & $55 \%$ \\
& Total & 100 & $100 \%$ \\
\hline
\end{tabular}

Sumber: Hasil olahan data penelitian (2013)

\section{Hasil Uji Validitas dan Reliabilitas}

Hasil pengujian validitas menunjukkan bahwa nilai semua item dinyatakan valid dilihat dari nilai $r$ hitung $>r$ tabel. Pada sig 0,05 dengan $\mathrm{n}=100$ dan $\mathrm{df}=98$ maka $\mathrm{r}$ tabel= 0,1966 . Pada pengujian reliabilitas menunjukkan bahwa Cronbach Alpha semua tabel $>0,60$ yang data dalam penelitian ini reliabel.

\section{Hasil Uji Discriminant analysis}

Kelompok yang dibedakan: (1) Pekerjaan yang berhubungan dengan keuangan (Keuangan), diberi kode 1; (2) Pekerjaan yang tidak berhubungan dengan keuangan (Non Keuangan), diberi kode 2.

Variabel independen terdiri dari: persepsi, motivasi, learning process, produk, harga, tempat/lokasi, promosi, orang/ SDM, proses, bukti fisik dan customer service. Berdasarkan hasil $F$ test menunjukkan bahwa variabel yang signifikan membedakan adalah motivasi dengan tingkat signifikansi 0,03 dan bukti fisik dengan ingkat signifikansi 0,006

Wilks lamda menunjukkan sig 0,006 yang lebih kecil daripada alpha 5\% artinya terdapat perbedaan yang signifikan antara perilaku kedua kelompok. Tabel eigen value menunjukkan angka 0,314 artinya varians dari variabel independen dapat dijelaskan oleh model discriminant yang terbentuk sebesar $31,4 \%$

Variabel yang signifikan membedakan kedua group adalah motivasi dan bukti fisik. Nilai rata-rata dan standar deviasi dari variabel yang signifikan membedakan kedua kelompok.

Dari table canonical diperoleh persamaan regresi berganda analysis discriminant: Zscore $=-1,74+2,21$ motivasi $-1,655$ bukti fisik. Artinya Kelompok yang bekerja disektor keuangan lebih mengutamakan motivasi sementara itu kelompok yang bekerja disektor non keuangan lebih mengutama kan bukti fisik.

Kelompok yang dibedakan: (1) Jenis kelamin laki laki, diberi kode 1; (2) Jenis kelamin perempuan, diberi kode 2 . 
Tabel 5

Nilai Rata-Rata dan Standar Deviasi Motivasi dan Bukti Fisik

\begin{tabular}{lcc}
\hline \hline Kelompok & $\begin{array}{c}\text { Nilai rata rata dan standar } \\
\text { deviasi dari motivasi }\end{array}$ & $\begin{array}{c}\text { Nilai rata rata dan standar } \\
\text { deviasi dari bukti fisik }\end{array}$ \\
\hline \multirow{2}{*}{ Keuangan } & Mean 3,47 & Mean 3,19 \\
\multirow{2}{*}{ Non Keuangan } & Stdev 0,48 & Stdev 0,36 \\
& Mean 3,2 & Mean 3,3 \\
\hline
\end{tabular}

Sumber : Hasil olahan data penelitian (2013)

Hasil $F$ test menunjukkan bahwa variabel yang signifikan membedakan adalah produk dengan tingkat signifikansi 0,013. Wilks lamda menunjukkan sig 0,013 yang lebih kecil daripada alpha 5\% artinya terdapat perbedaan yang signifikan antara perilaku kedua kelompok. Tabel eigen value menunjukkan angka 0,246 artinya varians dari variabel independen dapat dijelaskan oleh model discriminant yang terbentuk sebesar $24,6 \%$

Variabel yang signifikan membedakan kedua kelompok adalah produk. Nilai ratarata dan Standar Deviasi dari Variabel yang Signifikan membedakan kedua kelompok:

Tabel 6

Nilai Rata-Rata dan Standar Deviasi Dari Produk

\begin{tabular}{lc}
\hline Kelompok & $\begin{array}{c}\text { Nilai Rata Rata Dan Standar Deviasi } \\
\text { Dari Produk }\end{array}$ \\
\hline \multirow{2}{*}{ Laki Laki } & Mean 3,06 \\
& Stdev 0,511 \\
Perempuan & Mean 3,29 \\
& Stdev 0,36 \\
\hline
\end{tabular}

Sumber: Hasil olahan data penelitian (2013)

Dari table canonical diperoleh persamaan regresi berganda analysis discriminant: Zscore $=-7,411+2,32$ Produk. Artinya: Kelompok perempuan lebih memperhatikan variasi produk, manfaat, metode, likuiditas, dan inovasi produk. Perempuan lebih cermat mengamati produk keuangan dalam pengambilan keputusannya. Berdasarkan table classification result diperoleh ketepatan klasifikasi sebesar 59\%.

Kelompok yang dibedakan: (1) Financial knowledge tinggi (skor di atas rata rata), diberi kode 1; (2) Financial knowledge rendah (skor di bawah rata rata), diberi kode 2. Hasil $\mathrm{F}$ test menunjukkan bahwa variabel yang signifikan membedakan adalah persepsi dengan tingkat signifikansi 0,004 , di bawah 5\%. Wilks lamda menunjukkan sig 0,004 yang lebih kecil daripada alpha $5 \%$ artinya terdapat perbedaan yang signifikan antara perilaku kedua kelompok. Tabel eigen value menunjukkan angka 0.289 artinya varians dari variabel independen dapat dijelaskan oleh model discriminant yang terbentuk sebesar $28,9 \%$

Variabel yang signifikan membedakan kedua group adalah persepsi. Nilai rata-rata dan Standar Deviasi dari Variabel yang Signifikan membedakan kedua kelompok.

Dari table canonical diperoleh persamaan regresi berganda analysis discriminant: Zscore $=-5,917+1,853$ Persepsi. Artinya kelompok yang memiliki financial knowledge rendah, di bawah nilai rata-rata, lebih mengutakamakan persepsi dalam pengambilan keputusan investasi jika dibandingkan dengan kelompok yang memiliki financial knowledge yang tinggi. Dari table classification result diperoleh ketepatan klasifikasi sebesar 62\%. 
Tabel 7

Nilai Rata-Rata dan Standar Deviasi Dari Persepsi

\begin{tabular}{cc}
\hline Group & Nilai Rata Rata Dan Standar Deviasi Dari Persepsi \\
\hline \multirow{2}{*}{ Financial Knowledge Tinggi } & Mean 3,015 \\
& Stdev 0,643 \\
Financial Knowedge Rendah & Mean 3,339 \\
& Stdev 0,437 \\
\hline
\end{tabular}

Sumber: Hasil olahan data penelitian (2013)

Kelompok yang dibedakan: (1) Usia yang lebih kecil sama dengan 40 tahun; (2) Usia yang lebih dari 40 tahun. Hasil menunjukkan bahwa tidak ada satu variabel pun yang signifikan membedakan kedua kelompok ini dalam pengambilan keputusan investasi. Artinya faktor usia tidak membedakan proses keputusan investasi keuangan dari para investor.

\section{Pembahasan Hasil Uji Disccriminant}

Hasil penelitian menunjukkan bahwa:

(1) Terdapat perbedaan signifikan antara perilaku keputusan investasi berdasarkan jenis pekerjaan. Dimana pekerjaan yang berhubungan dengan keuangan cenderung melakukan keputusan investasi lebih menekankan kepada aspek motivasi, sementara itu untuk kelompok pekerjaan yang berada pada sektor keuangan lebih mengutamakan bukti fisik. Hasil penelitian ini membuktikan bahwa mereka yang bekerja disektor keuangan memiliki pengetahuan yang jelas tentang investasi keuangan sehingga mereka mengetahui dengan pasti return dan manfaat yang diperoleh melalui investasi tersebut yang akhirnya menjadi motivasi bagi mereka untuk berinvestasi. Hal ini berbeda sekali dengan mereka yang bekerja disektor non keuangan yang lebih mengutamakan bukti fisik dalam melakukan investasi keuangan seperti: kondisi gedung dan ruang tunggu yang nyaman, penampilan karyawan yang rapih dan bersih. Hal ini mungkin disebabkan karena kurangnya pengetahuan mereka terhadap investasi keuangan, sehingga investor tersebut tidak dapat memprioritaskan faktorfaktor yang memang dibutuhkan dalam keputusan investasinya. Hasil Penelitian ini mendukung penelitian Lewellen et al. (1977) bahwa faktor demografi seperti pekerjaan mempengaruhi seseorang dalam proses keputusan investasi keuangannya. Demikian juga menurut Kotler dan Amstrong (2008) keputusan konsumen dalam hal ini investor keuangan dalam memilih jasa keuangan juga dipengaruhi oleh karakteristik pribadi antara lain jenis pekerjaan mereka; (2) Kehangatan emosionalitas, di samping itu memiliki sikap ke hati-hatian dan sensivitas yang lebih tinggi dari pada pria. Perempuan lebih kepada produk, oleh karena itu wanita lebih memperhatikan resiko dan return pada suatu produk investasi; (3) Hasil Penelitian menunjukkan bahwa terdapat perbedaan yang signifikan antara kelompok investor yang memiliki financial knowladge yang tinggi dan yang memiliki financial knowladge yang rendah dalam proses keputusan investasi keuangan nya. Kelompok yang memiliki financial knowledge rendah (dibawah nilai rata-rata) lebih mengutamakan persepsi dalam pengambilan keputusan investasi. Hal ini disebabkan karena mereka tidak mengerti tentang investasi keuangan, sehingga ketika mereka merasa investasi itu aman serta menjanjikan dan uang mereka ada, pasti mereka mau malakukan investasi. Hasil penelitian ini sejalan dengan penelitian yang dilakukan oleh Jain dan Mandot (2012) yang membuktikan bahwa terdapat korelasi positif antara pengetahuan dengan keputusan untuk berinvestasi.

Disamping itu menurut Kotler dan Amstrong (2008), keputusan konsumen dalam hal ini investor keuangan juga dipengaruhi oleh pengetahuan mereka akan produk/jasa seperti manfaat yang lebih dari produk/jasa yang mereka konsumsi di bandingkan produk yang lain, sehingga me- 
nambah rasa percaya diri dalam pengkonsumsian produk/jasa tersebut; (4) Hasil penelitian menunjukkan bahwa tidak terdapat perbedaan antara kelompok usia yang lebih kecil sama dengan 40 dengan kelompok usia yang lebih besar dari 40 dalam proses keputusan investasi keuangannya. Artinya faktor usia tidak membedakan proses keputusan investasi keuangan dari para investor. Hal ini dapat diterima secara rasional bahwa ketika seseorang memutuskan untuk melakukan investasi keuangan biasanya sangat dipengaruhi oleh tingkat pengetahuan keuangan yang cukup tinggi, dan bukan hanya didasarkan oleh usia. Hasil penelitian ini berbeda dengan pendapat Kotler dan Amstrong (2008), yang menyatakan bahwa keputusan konsumen dipengaruhi oleh siklus hidup termasuk usia. Hasil penelitian ini juga berbeda dengan kajian yang dilakukan Jain dan Mandot (2012), yang membuktikan terdapat korelasi usia terhadap keputusan investasi. Disamping itu, hasil penelitian ini tidak mendukung kajian yang dilakukan oleh Lewellen et al. (1977), yang membuktikan bahwa variabel demo- grafi antara lain usia mempengaruhi keputusan investasi dari para investor.

\section{Hasil Uji Regresi Linear Berganda}

Terlihat dari output bahwa model variabel yang signifikan dimasukkan hanyalah proses, motivasi dan customer service, sedangkan variabel lainnya tidak dimasukkan.

Pada Model I yang menjadi variabel predictor (independent) hanyalah proses. Nilai $\mathrm{R}=0,498$ artinya variasi proses sangat erat hubungannya dengan keputusan, sedangkan nilai R Square sebesar 0,248 berarti $24,8 \%$ faktor-faktor keputusan konsumen dapat dijelaskan oleh variabel proses sedangkan sisanya $75,2 \%$ dapat dijelaskan oleh faktor lain yang tidak diteliti oleh penelitian ini. Standard error of estimate adalah 0,39053 semakin kecil standar deviasi berarti model semakin baik.

Pada Model II dapat dilihat bahwa yang menjadi variabel predictor (independent) adalah variabel proses dan motivasi. Nilai $\mathrm{R}=0,555$ artinya variasi proses dan motivasi sangat erat hubungannya dengan keputusan, sedangkan nilai $\mathrm{R}$ Square sebesar

Tabel 8

Variables Entered/Removed (a)

\begin{tabular}{clcl}
\hline \hline Model & $\begin{array}{c}\text { Variables } \\
\text { Entered }\end{array}$ & $\begin{array}{c}\text { Variables } \\
\text { Removed }\end{array}$ & \multicolumn{1}{c}{ Method } \\
\hline 1 & Proses & $\cdot$ & $\begin{array}{l}\text { Stepwise (Criteria: Probability-of-F-to-enter }<=, 050, \\
\text { Probability-of-F-to-remove }>=, 100) .\end{array}$ \\
2 & Motivasi & $\cdot$ & $\begin{array}{l}\text { Stepwise (Criteria: Probability-of-F-to-enter }<=, 050, \\
\text { Probability-of-F-to-remove }>=, 100) .\end{array}$ \\
3 & $\begin{array}{l}\text { Customer } \\
\text { Service }\end{array}$ & $\cdot$ & $\begin{array}{l}\text { Stepwise (Criteria: Probability-of-F-to-enter }<=, 050, \\
\text { Probability-of-F-to-remove }>=, 100) .\end{array}$ \\
\hline
\end{tabular}

a Dependent Variable: Keputusan Konsumen Sumber : Hasil olahan data penelitian (2013)

Tabel 9

Model Summary

\begin{tabular}{ccccc}
\hline \hline Model & R & R Square & Adjusted R Square & Std. Error of the Estimate \\
\hline 1 &, $498(\mathrm{a})$ &, 248 &, 241 &, 39053 \\
2 &, $555(\mathrm{~b})$ &, 308 &, 294 &, 37664 \\
3 &, $583(\mathrm{c})$ &, 340 &, 319 &, 36974 \\
\hline
\end{tabular}

a Predictor s: (Constant), Proses

b Predictor s: (Constant), Proses, Motivasi

c Predictor s: (Constant), Proses, Motivasi, Customer Service

Sumber: Hasil Olahan Data Penelitian (2013) 
0,308 berarti 30,8\% faktor-faktor keputusan konsumen dapat dijelaskan oleh variabel proses dan motivasi sedangkan sisanya $69,2 \%$ dapat dijelaskan oleh faktor lain yang tidak diteliti oleh penelitian ini. Standard error of estimate adalah 0,37664 semakin kecil standar deviasi berarti model semakin baik.

Pada Model III diketahui bahwa yang menjadi variabel predictor (independent) adalah variabel proses, motivasi, dan customer service. Nilai $\mathrm{R}=0,583$ artinya variasi proses, motivasi, dan customer service sangat erat hubungannya dengan keputusan, sedangkan nilai R Square sebesar 0,340 berarti 34\% faktor-faktor keputusan konsumen dapat dijelaskan oleh variabel proses, motivasi, dan customer service, sedangkan sisanya $66 \%$ dapat dijelaskan oleh faktor lain yang tidak diteliti oleh penelitian ini. Standard error of estimate adalah 0,36974 semakin kecil standar deviasi berarti model semakin baik.

Tabel 10

$\operatorname{ANOVA}^{(d)}$

\begin{tabular}{clccccc}
\hline \hline Model & & Sum of Square s & Df & $\begin{array}{c}\text { Mean } \\
\text { Square }\end{array}$ & F & Sig. \\
\hline 1 & Regression & 4,939 & 1 & 4,939 & 32,385 &, $000(\mathrm{a})$ \\
& Residual & 14,946 & 8 &, 153 & & \\
& Total & 19,885 & 9 & & & \\
2 & Regression & 6,125 & 2 & 3,062 & 21,587 &, $000(\mathrm{~b})$ \\
& Residual & 13,760 & 7 &, 142 & & \\
& Total & 19,885 & 9 & & & \\
3 & Regression & 6,761 & 3 & 2,254 & 16,485 &, $000(\mathrm{c})$ \\
& Residual & 13,124 & 6 &, 137 & & \\
& Total & 19,885 & 9 & & & \\
\hline
\end{tabular}

\footnotetext{
A Predictor S: (Constant), Proses

B Predictor S: (Constant), Proses, Motivasi

C Predictor S: (Constant), Proses, Motivasi, Customer Service

D Dependent Variable: Keputusan Konsumen

Sumber : Hasil olahan data penelitian, (2013)
}

\section{Model I}

Tabel 10 mengungkapkan bahwa nilai $F$ hitung adalah 32,385 dengan tingkat signifikansi 0,000 , sedangkan $\mathrm{F}$ tabel pada tingkat kepercayaan 95\% $(\alpha=0,05)$ adalah 0,26 . Karena $F$ hitung $>F$ tabel dan tingkat signifikansinya $(0,000)<(0,05)$ hal ini menunjukkan bahwa pengaruh variabel independen proses berpengaruh secara signifikan terhadap keputusan konsumen.

\section{Model II}

Nilai F hitung adalah 21,587 dan tingkat signifikansi 0,000 . Nilai $\mathrm{F}$ tabel pada tingkat kepercayaan $95 \% \quad(\alpha=0,05)$ adalah 0,26 . Oleh karena pada kedua perhitungan yaitu $F$ hitung $>F$ tabel dan tingkat signifikansinya $(0,000)<(0,05)$ ini menunjukkan pengaruh variabel independen proses dan motivasi berpengaruh secara signifikan terhadap keputusan konsumen.

\section{Model III}

Nilai F hitung adalah 16,485 dan tingkat signifikansi 0,000 . Nilai $\mathrm{F}$ tabel pada tingkat kepercayaan 95\% $(a=0,05)$ adalah 0,26 . Karena $F$ hitung $>F$ tabel dan tingkat signifikansinya $(0,000)<(0,05)$ hal ini menunjukkan bahwa pengaruh variabel independen proses, motivasi dan customer service berpengaruh secara signifikan terhadap keputusan konsumen. 
Tabel 11

Coefficients(a)

\begin{tabular}{|c|c|c|c|c|c|c|}
\hline \multirow[t]{2}{*}{ Model } & & \multicolumn{2}{|c|}{$\begin{array}{c}\text { Unstandardized } \\
\text { Coefficients }\end{array}$} & \multirow{2}{*}{$\begin{array}{c}\begin{array}{c}\text { Standardized } \\
\text { Coefficients }\end{array} \\
\text { Beta } \\
\end{array}$} & \multirow{2}{*}{$\frac{t}{B}$} & \multirow{2}{*}{$\frac{\text { Sig. }}{\text { Std. Error }}$} \\
\hline & & $\mathrm{B}$ & Std. Error & & & \\
\hline \multirow[t]{2}{*}{1} & (Constant) & 1,927 & ,248 & & 7,769 & , 000 \\
\hline & Proses & ,402 & ,071 & ,498 & 5,691 & ,000 \\
\hline \multirow[t]{3}{*}{2} & (Constant) & 1,383 & ,304 & & 4,550 & ,000 \\
\hline & Proses &, 300 & ,077 & ,372 & 3,911 & ,000 \\
\hline & Motivasi & ,274 & ,095 & 275 & 2,891 & ,005 \\
\hline \multirow[t]{4}{*}{3} & (Constant) & 1,096 & ,327 & & 3,351 & ,001 \\
\hline & Proses & 181 & ,093 & ,225 & 1,946 & ,055 \\
\hline & Motivasi & 269 & ,093 & 270 & 2,892 & ,005 \\
\hline & Customer Service & 208 & ,096 & ,233 & 2,157 & ,033 \\
\hline
\end{tabular}

a Dependent Variable: Keputusan Konsumen Sumber : Hasil olahan data penelitian (2013)

\section{Pembahasan Hasil Uji Regresi Stepwise}

Stepwise regresion merupakan kombinasi forward dan backward. Melalui model ini dapat diketahui variabel yang tidak signifikan pengaruhnya terhadap variabel dependen secara otomatis akan dikeluarkan dari model, sehingga hanya variabel bebas yang memiliki pengaruh signifikan yang akan digunakan.

Pada Model I.

$\mathrm{Y}=1,927+0,402$ Proses.

Standard error $=0,071$ artinya standar deviasi dari rata-rata nilai produk adalah 0,071.

Pada Model II.

$\mathrm{Y}=1,383+0,300$ proses $+0,274$ Motivasi.

Standard error $1=0,077$ artinya standar deviasi dari rata-rata nilai produk adalah 0,077 . Standard error $2=0,095$ artinya standar deviasi dari rata-rata nilai produk adalah 0,095.

Pada Model III.

$\mathrm{Y}=1,096+0,181$ Proses + 0,269 Motivasi + 0,208 Customer service.

Standard error $1=0,093$ artinya standar deviasi dari rata-rata nilai produk adalah 0,093 . Standard error $2=0,093$ artinya standar deviasi dari rata-rata nilai produk adalah 0,093. Standard error $3=0,096$ artinya standar deviasi dari rata-rata nilai produk adalah 0,096.
Berdasarkan hasil uji regresi stepwise dapat diketahui bahwa model III adalah yang terbaik, dimana menunjukkan bahwa proses, motivasi, dan customer service berpengaruh positif dan signifikan terhadap keputusan investor untuk melakukan investasinya. Hasil penelitian membuktikan bahwa ternyata investor sangat memperhatikan dan mempertimbangkan aspek proses dalam pelayanan keuangan. Artinya bagaimana proses pelayanan keuangan yang diberikan kepada mereka selama ini menjadi salah satu indikator dalam atribut jasa. Hasil penelitian ini mendukung kajian yang dilakukan oleh Gronross dalam Tjiptono (2005), dimana untuk mengetahui pelayanan itu berkualitas dapat dilihat dari dua dimensi yaitu dari technical quality dan process quality atau kualitas pelayanan dari aspek bagaimana pelayanan itu diberikan oleh penyedia jasa kepada penerima jasa. Hasil kajian Gronross ini juga membuktikan bahwa pada dasarnya bagi jenis pelayanan yang sifatnya kompleks dan teknis seperti perbankan atau pelayanan jasa keuangan maka proses quality (kualitas dari proses) pada pelayanan yang diberikan lebih mempengaruhi keputusan konsumen untuk berinvestasi bahkan sampai kepada keputusan pasca pembelian dalam hal ini kepuasan dan loyalitas konsumen jasa. 
Hasil penelitian ini juga membuktikan bahwa motivasi yang merupakan bagian dari aspek psikologis juga merupakan faktor yang mempengaruhi keputusan investor untuk berinvestasi. Keputusan investasi seseorang bisa saja berbeda-beda berdasarkan apa yang memotivasi mereka untuk memilih jenis investasi tersebut, seperti: melakukan investasi keuangan untuk mengurangi resiko ketidak pastian dimasa yang akan datang, untuk memperoleh return atau deviden yang diharapkan, atau untuk mencapai target hidup.

Disamping itu, hasil penelitian juga menunjukkan bahwa customer service atau layanan kepada pelanggan juga berpengaruh signifikan terhadap keputusan untuk berinvestasi. Hal ini tentu saja sangat rasional, dimana pelayanan keuangan adalah jenis pelayanan yang merupakan jenis pelayanan yang sangat teknis dan kompleks (customer contact) tinggi, sehingga sangat diperlukan sekali pelayanan yang bersifat individu kepada para nasabahnya, seperti: Perusahaan jasa keuangan dapat memberikan pelayanan kepada nasabahnya dengan sepenuh hati, memberikan pelayanan sesuai dengan kebutuhan nasabah, memberikan pelayanan dengan cepat, serta penyediaan call centre atau pusat informasi dan aduan 24 jam selama 7 hari.

Hasil penelitian ini sejalan dengan teori Kotler dan Amstrong (2008), yang menyatakan bahwa untuk bidang jasa/pelayanan memang memerlukan tambahan instrumen pemasaran disamping instrumen pemasaran untuk barang berwujud yaitu diantaranya ada proses, dan customer service. Oleh karena itu, mengingat teknisnya jenis pelayanan keuangan, maka sangat diperlukan kemampuan penyedia jasa keuangan untuk memberikan perhatian dan pelayanan secara tulus kepada nasabah mereka terutama berkenaan dengan penyampaian informasi yang akurat dan jelas tentang produk investasi kepada investor atau nasabah.

\section{SIMPULAN DAN SARAN Simpulan}

Simpulan penelitian ini adalah sebagai berikut: Pertama, terdapat perbedaan yang signifikan antara perilaku keputusan investasi berdasarkan jenis pekerjaan. Dimana pekerjaan yang berhubungan dengan keuangan cenderung melakukan keputusan investasi lebih menekankan kepada aspek motivasi, sementara itu untuk kelompok pekerjaan yang berada pada sektor keuangan lebih mengutamakan bukti fisik. Kedua, terdapat perbedaan yang signifikan antara kelompok investor yang berjenis kelamin perempuan dan berjenis kelamin laki-laki dalam proses keputusan investasi keuangannya. Kelompok perempuan lebih memperhatikan variasi produk, manfaat, metode, likuiditas dan inovasi produk. Ketiga, terdapat perbedaan yang signifikan antara kelompok investor yang memiliki financial knowledge yang tinggi dan yang memiliki financial knowledge yang rendah dalam proses keputusan investasi keuangannya. Kelompok yang memiliki financial knowledge rendah (dibawah nilai rata-rata) lebih mengutamakan persepsi dalam pengambilan keputusan investasi. Keempat, tidak terdapat perbedaan kelompok usia terhadap keputusan investasi keuangan. Artinya faktor usia tidak membedakan proses keputusan investasi keuangan dari para investor. Kelima, proses, motivasi dan customer service berpengaruh positif dan signifikan terhadap keputusan investor untuk berinvestasi.

\section{Saran}

Berdasarkan simpulan hasil penelitian yang telah dikemukakan, maka saran-saran yang diajukan adalah sebagai berikut: Pertama, sebaiknya perusahaan jasa investasi keuangan memperhatikan variabel demografi (pekerjaan, jenis kelamin, financial knowledge dan usia) dari para investor atau calon investor, dan menyesuaikan 
strategi pemasarannya untuk masingmasing kelompok dari variabel demografi, seperti: inovasi terhadap produk/jasa keuangan, serta penyampaian informasi dan komunikasi yang efektif tentang jasa investasi keuangan untuk meningkatkan financial knowledge dari para investor. Kedua, bagi peneliti selanjutnya diharapkan dapat menemukan variabel-variabel lain yang membedakan proses keputusan investasi keuangan para investor yang akhirnya akan mempengaruhi keputusan investasi keuangan dari para investor.

\section{DAFTAR PUSTAKA}

Arikunto, S. 2002. Prosedure Penelitian. Rineka Cipta Bumi Aksara. Jakarta.

Al-Tamimi, H. dan A. Hassan. 2006. Factors Influencing Individual Investor Behavior: An Empirical Study of the UAE Financial Markets. The Business Review $5(2)$.

Andreassen dan T. Walin. 1994. Satisfaction Loyalty and Reputation as Indicators of Customer Orientation in the Public Sector. International Journal of Public Sector Management 7(2).

Badriyah, L. 2013. Ciri-ciri Investasi Bodong: Iming-iming Tak Berpotensi Rugi. http: www.metrotonews.com/ metronews. Diakses tanggal 22 Maret 2013.

Barber, B. M. dan T. Odean. 2000. Trading is Hazardous to Your Wealth: The Common Stock Investment Performance of Individual Investors. The Journal of Finance 55(2): 773-80.

------. 2002. All That Glitters: The Effect of Attention and News on the Buying Behavior of Individual and Institutional Investors. Working Paper. Berkeley UC.

-----. 2001. Boys Will Be Boys; Gender, Overconfidene and common Stock Investment. Quarterly Journal of Economics 116: 261-292.

Bloemer, Josee, K. D. Ruyter dan P. Pasca. 1998. Investigating Drivers of Bank Loyalty: The Complex Relationship between Image, Service Quality, and
Satisfaction. International Journal of Bank Marketing 17(7).

Blume, M. E. dan I. Friend. 1978. The Changing Role of the Individual Investor. John Wiley and Sons. New York.

Chen, T. Y. 1999. Critical Success Factors for Various Strategies in the Banking Industry. International Journal of Banking Marketing 17(2).

Djumaeni, E. 2013. Ini Daftar Investasi Bodong yang sudah Makan Korban. Kompas. http: www.Bisnis keuangan. Kompas.com. Diakses tanggal 25 Maret 2013.

Ferdinand, A. 2006. Metode Penelitian Manajemen. Edisi ke-2. Badan Penerbit Universitas Diponegoro. Semarang.

Ghozali, I. 2006. Aplikasi Analisis Multivariate dengan Program SPSS. Edisi Keempat. Badan Penerbit Universitas Diponegoro. Semarang

------. 2011. Aplikasi Multivariate Lanjutan Dengan Program SPSS. Badan Penerbit Universitas Diponegoro. Semarang.

Halim, A. 2005. Analisis Investasi. Edisi Ke-2. Salemba Empat. Jakarta.

Iramani, R. dan D. B. Permana. 2008. Faktorfaktor Penentu Perilaku Investor dalam Transaksi Saham di Surabaya. The Journal of Economics Pasca Sarjana STIE Perbanas Surabaya.

Jain, D. dan M. Nikhil. 2012. Impact of Demographic Factors on Investment Decision of Investors In Rajahsthan. Journal of Arts, Science and Commerce 3(2): 81-92.

Kabra, Gaurav, Mishra, P. Kumar dan M.K. Kumar. 2010. Factors Influencing Investment Decision of Generations in 'India: An Econometric Study. Asian Journal of Management Research: 308-326.

Karthikeyan, B. 2001. Small Investors' Perception on Post Office Small Savings Schemes'. Unpublished Thesis. Madras University. Tamilnadu India.

Kotler, P. dan G. Amstrong. 2008. PrinsipPrinsip Pemasaran. Jilid 1. Edisi ke-12. Erlangga. Jakarta. 
Kumar, A. 2009. Dynamic Style Preferences of Individual Investors and Stock Return. Journal of Financial and Quantitative Analysis 44(3): 607-640.

Laksana, F. 2008. Manajemen Pemasaran Pendekatan Praktis. Penerbit Graha Ilmu. Yogyakarta.

Lewellen, W. G., R. C. Lease dan G. C. Schlarbaum. 1977. Patterns of Investment Strategy and Behavior among Individual Investor. Journal of Business: 296-333.

Meliza, J. 2014. Analisis Pengaruh Pengaruh Perilaku Keuangan Terhadap Keputusan Investor dan Performa Investasi Saham di Kota Medan. Jurnal Manajemen PRIMA 4(1): 15-35.

Nagy, R. A. dan R. W. Obenberger. 1994. Factors Influencing Individual Investor Behavior. Financial Analysts Journal: 6368.

Odean, T. 1999. Do investors trade too much? Journal of American Economic Review 89(5): 1279-1298.

Rabin, M. 2002. Inference by Believers in the Law of Small Numbers. Quarterly Journal of Economics 117(3): 775-816.

Sumanto. 2002. Pembahasan Terpadu Statistika $\mathcal{E}$ Metodologi Riset. Andi. Yogyakarta.
Tjiptono, F. 2005. Pemasaran Jasa. Bayumedia Publishing. Malang Jawa Timur.

Toral, A. 2002. Other Ways to Score Invesment Points. Pure Fundamentalist.

Von Neumann, S. J. dan O. Morgenstern. 1947. Theory of Games and Economic Behavior. Princeton University Press. Princeton.

Wang, A. 2001. Overconfidance, Investor Sentiment and Evolution. Journal of Financial Intermediation 10(2): 138-170.

Warren, W. E., R. E. Stevens dan C. W. McConkey. 1990. Using Demographic and Lifestyle Analysis to Segment Individual Investor. Financial Analysts Journal.

Waweru, N., M. Munyoki dan E. Uliana. 2008. The Effects of Behavioral Factors in Investment Decision-Making: a Survey of Institutional Investors Operating at the Nairobi Stock Exchange. International Journal of Business and Emerging Markets 1(1): 24-41.

Yamin, S. dan K. Heri. 2009. SPSS Complete: Teknik Analisis Statistik Terlengkap SPSS. Seri 1. Salemba Empat. Jakarta.

Zuckerman, M., E. A. Kolin, L. Price dan I. Zoob. 1964. Development of a Sensation-Seeking Scale. Journal of Consulting Psychology 28(6): 477-482. 